\title{
Political Trust in France's multi-level government
}

\author{
Authors: Alistair Cole (Sciences Po, Lyon, France), Stuart Fox (WISERD, Wales, UK) \\ Romain Pasquier (Sciences Po Rennes, France) and Ian Stafford (Cardiff University, UK)
}

Trust has long been identified as an essential component of social, economic and political life. Since the mid-1990s, as Newton (2007, p.342) notes, there has been an 'explosion of interest' in the concept driven by its perceived decline and reengagement with concepts of social capital (Putnam 1993, 2000; Fukuyama 1995; Seligman 1997; Braithwaite \& Levi 1998; Warren 1999a; Hardin 2002, 2006; Keele, 2007; Uslaner 2002; Hetherington, 2005; Zmerli \& Hooghe 2011). The wider literature on political trust has identified a range of potential factors underpinning trust, such as citizen satisfaction with policy, economic performance, the prevalence of political scandals and corruption and the influence of social capital. Parker et al. (2014, 87) sum up the underlying assumption in much of the literature that 'the public is more trusting when they are satisfied with policy outcomes, the economy is booming, citizens are pleased with incumbents and institutions, political scandals are non-existent, crime is low, a war is popular, the country is threatened, and social capital is high.'

The article acknowledges these debates, especially the general context of decline in trust in western democracies, including in France, our country case (Balme, Rosenberg \& Marie, 2003; Boy \& 
Chiche, 2010; Cautrès, 2017; CEVIPOF, 2014; CEVIPOF, 2015; Dogan, 1999; Grossman \& Sauger, 2017; Pew Research, 2017). It is framed to answer a more parsimonious question, however. The analysis developed within this paper considers political trust within multiple layers of government at a single point and therefore provides a clearer picture of how citizens engage with complex governance arrangements where the primary responsibility for specific policy areas is often unclear. While attempts to measure or evaluate levels of political trust have generally been applied to the local or national level or, within the European context, the EU level (Citrin \& Muste 1999; Kaase 1999; van de Walle et al. 2008; Muñoz et al. 2011; van der Meer \& Hakhverdian 2017), our article breaks new ground, by looking at how political trust varies within a multi-level governmental system.

This article reports findings from a major nationwide survey carried out from October 7-11 2016. It turns around how best to understand the drivers of political trust in political institutions in France in a context of multi-level government. While some descriptive data is presented and discussed, the focus is primarily on the use of latent structure analysis to explore the trust data itself, and regression models looking in more detail at predictors of high or low levels of trust in the different institutions of France's governmental system. All of the data and coding is available from the authors on request. The article is organized into four main sections. Section one operates a definition of political trust. Section two presents the research design and methods. Section three presents the results of latent structure analyses into the nature of measures of institutional trust. Section four then analyses institutional trust and identifies key demographic, regional and political traits that are associated with higher or lower levels of political trust. The article concludes that types of institution and forms of party identification matter more for political trust than socio- 
demographic or scalar explanations. The main contribution is to add a territorial dimension to debates on trust and to address the deficiency in the literature, which is dominated by studies of national or supranational trust.

\section{DEFINING TRUST}

Trust is perhaps one of the most contested concepts within contemporary academic debates. Levi (1998, 79 - quoted in Newton 2007, 343), for example, observes that trust 'is not one thing and it does not have one source; it has a variety of forms and causes.' Therefore grasping this concept, which is disputed both across and within multiple disciplines and operationalised in a variety of ways, remains a significant challenge. Trust is an object of theoretical controversy, pulled asunder by different theoretical chapels. In the rational choice tradition, Lenard $(2005,365)$ emphasises 'the strategic risk-taking elements of trust' and draws on rational choice theory to assume that 'both the truster and the trusted will act, in general, to maximise their own interests'. From a radically opposed perspective, trust is interpreted as a moral predisposition. Uslaner (2002, 17-18) argues that moralistic trust 'is a commandment to treat people as if they were trustworthy' and mostly does not depend upon personal experiences. Fisher et al. (2010) add a third approach, deliberative trust. They argue that trust performs the function of 'a facilitating mechanism for collective action that occurs through deliberation, innovation and co-operation rather than through a strategic, rational judgement of the trustee's interests or a moral judgement about human nature.' Thus defined, trust has been identified as a key factor in enabling cooperation 
and reducing uncertainty in complex decision-making networks (Koppenjan and Klijn 2004; Cole \& John, 2001; Stone, 1989).

'Trust' is here defined in rudimentary terms as the relationship between a subject (the one who trusts) and an object (the individual or entity which is trusted). It is a multidimensional concept, embracing inter-personal, social and political dimensions. A key distinction within the literature has been the identification of these different forms of trust. Zmerli and Newton $(2011,69)$ delineate three kinds of trust: 'particular social trust' which involves those that are known to us personally, such as family, friends or work colleagues; 'general social trust' which is that placed in 'unknown others'; and finally 'political trust' defined as 'either trust in particular politicians or trust in the main institutions of government and public life'. 'Particular social trust' or 'thick trust' is characterised as being inter-personal, described by Putnam $(2000,136)$ as 'embedded in personal relations that are strong, frequent and nested in wider networks.' However, this form of trust is inherently limited because outsiders or strangers are likely to be distrusted. In contrast, generalised social trust or 'thin trust' is centred on more general information about social groups and situations. This form of trust performs a key function in modern societies, as Newton $(2007,349)$ notes, because 'much social interaction is between people who neither know one another nor share a common social background.' These two forms of inter-personal trust contrast with most characterisations of political trust. Hooghe and Zmerli (2011, p.3) draw on Easton's (1965) idea of diffused support to characterize political trust as a 'very thin form of trust' characterised by a 'kind of general expectation that on the whole, political leaders will act according to the rules of the game as they are agreed upon in a democratic regime'. 
There has been much debate regarding how political trust can be conceptualised and measured. Hardin $(2002,152)$ argues that notions of trust in relation to government are not analogous to interpersonal trust; rather political trust is a form of 'quasi trust', an indirect relationship between citizens and political trustees based on perceived qualities such as the integrity, predictability, performance and efficiency of politicians. The key associations in the rich literature have been between trust, policy performance and social capital. Hetherington and Husser (2012 p. 312) define political trust 'as the ratio of people's evaluation of government performance relative to their normative expectations of how government ought to perform'. Keele (2007) also links trust with policy performance and proposes a long-term association between levels of political trust (measured by survey-based evaluations of policy performance over time) and social capital (a composite measure drawn from aggregate level data). In a variety of the policy performance debate, trust has also become embedded in debates on issue salience (Hetherington and Husser, 2012) and policy mood (Stimson 2004), the level of trust varying over time according to broader questions of performance and policy agendas. Using a mix of bespoke surveys and focus groups, Hibbing and Thiesse-Morse (2001) introduce the rather different dimension of 'process space', to refer to the broader democratic processes that encourage trust, rather than the narrower focus on policy outputs and outcomes. For their part, Taber and Lodge (2006) combines surveys and media content analysis to demonstrate the importance of ideological perceptions and the ever-present propensity for cognitive dissonance in the filtering of information. Taken as a whole, these definitions usually subordinate consideration of trust to something else: policy performance, social capital, issue-salience, policy mood, ideology or process environment. In these various works, trust is understood at a level 
once removed, as an intervening variable to explain variations in policy outputs, policy outcomes and political processes.

Our preference is to engage with one of the most recent definitions - that of Grimmelikhuijsen (2012, 54) - who provides a useful approach centred on three dimensions of trustworthiness. These dimensions are: perceived competence, which 'refers to whether people perceive a government organization to be capable, effective, skilful or professional in making decisions;' perceived benevolence, which 'refers to whether people think that a government organization genuinely cares about citizens' interests'; and perceived honesty, which 'implies that the government organization is perceived to keep commitments and tell the truth.' In this article, we adapt this definition to view political trust as a contextually/institutionally contingent phenomenon based on the perceived competence, and, to a lesser extent, benevolence and honesty of government.

\section{RESEARCH DESIGN}

\section{Case selection}

The survey forms part of a larger project on trust and transparency in multi-level governance in the UK, Germany and France. Multi-level governance (MLG) is understood here across its two principal dimensions: multiple levels of delivery and regulation of public services (from local to 
European), and multiple interactions, especially beyond the State, often involving the private delivery of public goods and assuming the role of lobbies and interests in policy formulation (Piatonni, 2010). The focus in this article is more specifically on the first dimension, multi-level government, in one of our cases, that of France. The choice of the French case captures contextually specific dynamics (the dispersion of policy-making dynamics in a formal unitary state), but also provides more general testable propositions in relation to other country cases, namely: the role of political trust in function-specific and general purpose forms of local and regional authority; the role of the State, residual or otherwise; the form of politics-policy dissonance in the pattern of multi-level public administration that characterizes contemporary government in general. ${ }^{1}$ Some of these themes are equally present in the rich US-based literature (e.g. Hibbing \& Theiss-Morse, 2001), but they are dealt with here in a European environment that is clearly distinctive from the US case.

These questions are pertinent across state form and especially in relation to our UK and German cases. They are especially germane for measuring the linkage of trust with more or less transparent forms of public administration. The primary focus on perceived competence is

\footnotetext{
${ }^{1}$ This article examines an emblematic case, rather than engaging in a comparison, stricto sensu. The broader project from which this article is drawn (name and title of project) is explicitly comparative, however. The project captures processes of trust and transparency (in multi-level governance) by comparing national, regional and city level dynamics in three states, by means of aggregate macro-level data, as well as ethnographic and experimental data drawn from a comparative analysis of six territories within three current EU member states: France (Brittany \& Auvergne-Rhône- Alpes), Germany (Hesse \& Saxony-Anhalt) and the United Kingdom (North West England \& Wales). Work is ongoing. The EU context provides the core similarity between these states, whose distinct state types cover the range of logical possibilities for comparison: a federal state (Germany), a predominantly unitary state modified by forms of asymmetrical devolution (United Kingdom), a decentralised but still unitary state (France).
} 
explained by the link of trust with transparency, understood in terms of policy delivery (where and by whom should policies be made). Who does what is not an easy question to answer in the French context. Various subnational authorities have overlapping territorial jurisdictions and loosely defined spheres of competence. There are now as many as six layers of public administration between the French citizen and Europe (commune, inter-communal structure, department, region, national government and European Union). The post-decentralisation French case provides an exemplar of what Hooghe and Marks (2001) describe as 'type 2 multi-level governance'. While the classic formulation of MLG (type 1) 'conceives of dispersion of authority to multi-task, territorially mutually exclusive jurisdictions in a relatively stable system with limited jurisdictional levels and a limited number of units', a second type 'pictures specialized, territorially overlapping jurisdictions in a relatively flexible, non-tiered system with a large number of jurisdictions' (Hooghe and Marks, 2001, p. 1). Borrowing a metaphor from the federalism literature, the French model of MLG is more akin to a marble cake (random and fruity), rather than a well-ordered layer cake, with neatly distributed competencies between levels (Entwistle et al., 2014). Unlike in many systems of territorial administration, there is no formal hierarchy between levels of local and regional authority. Since 2016, there have been 13 mainland regions (including Corsica), but they have lacked regulatory or law-making authority or an effective means of control over the other levels (see table 1)

--- Table 1 around here --- 
The EU dimension adds additional complexity: territorially, as there has been a gradual shift from a territorial narrative of strategic Europeanisation (whereby cities and regions use Europe to further their own ambitions and visions) to a practice of normative Europeanisation (whereby local and regional authorities are forced to adapt to a harsher EU-driven convergence) (Carter and Pasquier, 2010; Cole, et. al. 2015); politically, with the rise of eurosceptical forces and discourses in mainstream French politics, barely occulted by Macron's election as President in 2017 and functionally, as EU integration continues to challenge some important underpinnings of the French model of politics and policy.

\section{Measuring Political Trust}

The dominant method for measuring trust, both in terms of social and political trust, has been survey-based. There are a wide range of surveys that are utilised to underpin research on trust including the British Social Attitudes Survey (BSA), European Social Survey (ESS), Eurobarometer, American National Election Studies (ANES) and World Values Study (WVS). The combination of questions and indicators used to judge trust - in both social and political forms - varies from survey to survey. Seyd (2016) notes for example that the ANES comprises a battery of survey questions focused on trust but many surveys, such as the ESS and WVS, use single item survey measures. 
Typical of the single item survey response is the WVS. In the 2011 Questionnaire for the United States, for example, the following single item question was asked: 'Several groups of people are listed below. For each group, please indicate whether you trust people from this group completely, somewhat, not very much or not at all' (WVS Wave 6, 2010-2014). Likewise, the ESS (Questionnaire Round 8 2016/17) asked respondents how much they trust a list of institutions (parliament - the legal system - the police - politicians - political parties - European parliament the United Nations), in a way that does not facilitate finer grained or multi-level analyses. In the ANES, the Trust in Government Scale captures in a general sense trust in the honesty, benevolence and competence of the government in Washington, as measured by questions on the corruption of governmental officials, whether government is run by powerful interests and whether government can be trusted with taxes. While the ANES is an improvement on the ESS and WVS, the assumption is that trust is an undivided good that is not mediated by types of political institution.

The best-known example of a single question approach is that of the British Social Attitudes Survey, whose measure of political trust is whether individuals trust Members of Parliament to put the interests of the country ahead of those of their party. Implicit is the assumption that individuals who trust a particular actor or institution in one area (such as the integrity of Members of Parliament) also trust that actor or institution in other ways (for example in their willingness and capacity to deliver on their commitments). Such an assumption conceptualizes political trust as indivisible. From our perspective, it is surprising how much of the above cited scientific production does not question the formal definitions provided of trust, and assumes an ontological and epistemological coherence that cannot be challenged or contested. This precludes 
the possibility that political trust might be more nuanced and function-specific, with individuals having differing levels of trust in different institutions depending on their functions and responsibilities. This paper contends that context (including institutional context) is potentially key for understanding political trust (Zmerli and Hooghe 2011; Grimmelikhuijsen et al. 2013; Meijer 2013).

YouGov France conducted an internet-based survey of 3003 individuals, selected according to quotas of age, gender, region and social-professional category. As a prelude to data analysis, we confront the tricky issue of whether the questions asked in the survey actually measure trust (or, more specifically, the thin form of political quasi-trust, rather than the more interactive interpersonal or generic social trust). Amongst the various questions asked, respondents were invited to select which (if any) level of government they trusted to deal with a range of policy issues: insecurity, employment, education, immigration, social protection, the environment, national territory, debt, growth, housing, transport and tax. They were requested to select 'none', the national government, the municipal authority, the regional authority, the department, and the EU. The approach adopted in practice operationalizes political trust primarily on the basis of the perceived competence of government institutions to handle particular policy areas. The extent to which this can be characterised as 'trust' has been questioned (Nooteboom, 2002). Though it might be objected that trusting the integrity of a political institution and the competence of that institution are not the same thing, here we are assuming that they are, on the basis that politicians promise to address policy issues and social concerns, and their success or failure in doing so is perceived by voters as a deliberate failure to deliver on a promise, as well as an indication of competence. Former President Hollande’s failure to deliver on his repeated promise to bring 
down unemployment, for example, was viewed by voters as indicative either of his dishonesty (making an unrealistic promise) or, at least, as a sign of his unwillingness to deliver his promises, thereby diminishing trust in the Socialist President.

\section{METHODS \& ANALYSIS}

Two core lines of enquiry organized the data analysis. First, the question of the relationship between different expressions of political trust (specifically, generic and function specific trust) and, second, the correlates of political trust. While the first question addresses the blindspots of existing studies (especially those using single question survey items), the second contributes the data of our survey to discussions of the social-demographic and attitudinal underpinnings of trust.

The question regarding the relationship between different expressions of political trust is addressed using latent structure analysis (LSA). LSA allows for the relationship between different survey questions to be explored in terms of their representation of a common latent (i.e., unobserved) trait, based on the propensity of survey respondents to answer those various questions in ways that is indicative of a common relationship. Typically, such tests have been conducted using factor analysis in social and political science (e.g., Parry et al 1992; Campbell 2009; Pattie et al 2004; Chiche \& Chanvril, 2014), which assumes that the survey responses are essentially a function of a number of common causes (i.e., latent traits) and identifies the best number of 'factors' to represent them. Van der Eijk and Rose (2015), however, show that factor 
analysis has a tendency to over-estimate the number of latent traits represented by survey data (depending on its distribution). Moreover, factor analysis is based on the problematic assumption that individual respondents do not vary in their expression of traits through survey questions - it is only the questions that vary. This is hard to maintain when working with social survey data that is based on the assumption that individuals vary in terms of their expression of the characteristics measured, and is designed to capture as much of that variation as possible.

Van der Eijk and Rose (2015) instead recommend Mokken Scale Analysis (MSA), a method from the analytic family of item response theory and a probabilistic version of Guttman scaling that has been used for some years in educational research (Yamaguchi and Kandel 1984; Brookover et al 1964; Single et al 1974). MSA assumes that all survey variables are indicative of a common latent construct, in which differences in response reflect the varying ability (or in our case, willingness) of respondents to give a positive answer to the question (Van Schuur 2003). It then tests this hypothesis, and either confirms that all of the variables do indeed measure a common trait, or shows that an alternative structure should be identified (Van Schuur 2003; 2011). This method can be used to test the theory, therefore, that all indicators of political trust in our survey represent a common underlying propensity to trust (or not) a given political institution across all policy areas (i.e., generalised trust), or instead to suggest that trust in a given institution in one policy area is not related to trusting it in others at the same time (i.e., function-specific trust). The originality of this approach is that it potentially allows trust to manifest itself in distinctive ways according to the context of analysis; in the French case study we observe the expression of proximity trust for the lowest level of local government, the commune; a form of 
policy-specific intermediary trust for meso-level local and regional authorities and a more generic institutional trust for central government.

Using the techniques of Mokken Scale analysis, the article thus addresses the underlying question of whether trust is indivisible (respondents who express trust in one institution in one policy domain [for example the national government and the economy] also trust the same institution to deliver in other policy areas [for example, the national government and housing]), or whether, in a function-specific logic, citizens are more discerning and nuanced in their assessments of different levels of government.

The survey respondents were asked to indicate which (if any) level of government they trusted to deal with the twelve policy areas identified above. This data was recoded into a series of dichotomous measures relating to each institution for each policy area (e.g., identifying those who trusted the national government to deal with the economy and those who did not; those who trusted the department to deal with the economy and those who did not etc.), producing a total of 72 new variables. These were then analysed using MSA to identify clusters that were indicative of a common latent trait (such as a propensity to trust the national government across all policy areas).

The data collected relating to socio-demographic, political and contextual traits also makes it possible to examine how different expressions of trust may be related to characteristics known to be associated with trust in the extant literature. Previous research has shown that political trust 
can be shaped by one's age, gender, level of education, socio-economic status, social capital, cultural capital, and experience of participating in politics (Putnam 1995; Sintomer \& De Maillard 2007; Southwell 2012). To address our second question - regarding the relationship between different expressions of generalised or function-specific trust in political institutions and socio-demographic, political and contextual characteristics - we employed a combination of descriptive statistics and regression analyses, the results of which are presented below.

\section{DATA ANALYSIS}

\section{Institutional Trust \& Policy Competence}

The key headline finding of our survey revealed a deep mistrust in the functioning of French democracy, including in the 13 regions that were the specific target of the enquiry. Though barely one in two (46\%) declared that they were satisfied with the functioning of democracy in their region, this proportion was much higher than the corresponding figure at national level. In the CEVIPOF’s 2015 Barometer, fully 73\% considered that democracy was not functioning very well or not at all well. These findings are consistent with the literature that points to trends of mistrust being less pronounced at the local level than at the national level (Cheurfa 2017). The CEVIPOF's Trust Barometer asks the question 'do you trust the following institutions a great deal, somewhat, not much, or not at all'; the survey has consistently placed municipal government ahead, followed by the intermediary local and regional authorities, the national government, the presidency, the National Assembly, the European Union and organisations such 
as the G20. When the question is reframed in terms of individuals occupying institutional positions, the conclusions are similar: the mayor of the commune is trusted more than any other elected politician. That trust is enhanced by proximity is an intuitive finding that is backed up in our survey. In relation to the question 'which level is closest to the needs and preoccupations of the population?', the commune (28\%) emerges as the institution that is perceived to be closest to the needs and concerns of the population, ahead of the national government (16\%), the region (14\%), the department (13\%), and the European Union (4\%).

Table 2 shows the proportion of respondents who identified each political institution as the most trustworthy to handle each policy area, as well as the proportion who identified no institution as being trustworthy and those who did not know. The data shows that a substantial proportion of French citizens have no faith in any institution to deal with major contemporary policy issues. The institution that provides the most faith on average is the national government, though this is still amongst a minority of the population, with around one in five respondents trusting it to deal with their concerns. The municipal and regional authorities are trusted by an average of 13 and 14 per cent respectively, with the departments typically trusted by one in ten. The European Union is by far the least trusted institution, with only an average of three per cent believing it capable and willing to address their concerns.

Table 2 about here 
The average figures skew some variations in trust in each institution by policy area that are also noteworthy. While the national government is typically the most trusted institution, for example, fewer than one in ten trust it to address concerns relating to housing or transport, while one in three trust it to protect the national territory. Almost a third trust the municipal authorities to deal with housing, making them the most trusted institution in this area, while 29 per cent trust the regional authorities to address transport issues. Despite its very low average levels of trust, one in ten respondents trusted the EU most to address concerns relating to immigration and the environment. These variations by policy area suggest respondents' faith in the capacity and willingness of institutions to deal with policy concerns is conditioned by their perception of it actually having the responsibility to do so; trust in the national government, for example, is lowest with regards to housing and transport, issues over which the national government is perceived to have a limited influence. The institutions with the greatest influence over these issues - the municipal and regional authorities respectively - are the most trusted to deal with them. Support for the intermediary levels of sub-national government (13 regions and 96 departments) is sector and place specific, but provides a very thin form of legitimisation. The very low levels of trust in the EU (except in relation to immigration and the environment), confirm in some respects Schmidt’s (2006) dissociation between the national (politics without policy) and the EU (policy without politics) levels. If the national level is confronted with intense demands it cannot fulfil, the EU level ensures a key role in public policy regulation and elaboration which is barely acknowledged in public opinion. Such a politics-policy gap endears neither the central government, nor the EU. With echoes of Hibbing and Theiss-Morse's (2001, 145) 'policy gap', trust appears undermined by the perceived lack of transparency and the difficulty in understanding complex relationships and patterns of service delivery. 
Table 3 reports the results of the Mokken Scale Analysis, exploring the relationship between expressions of trust in institutions in relation to policy areas in more detail. The table reports the 'scales' identified in the analysis (i.e., clusters of variables that were shown to represent a common latent trait), as well as two Loevinger's H-coefficients. The h-coefficients for each individual variable show that the strength of association between it and the others in that scale in representing a common latent construct; the higher the coefficient, the stronger the association, with a minimum threshold of 0.3 being considered sufficient in the literature to conclude that the variables are measuring the same latent trait (Van Schuur 2003; Van der Eijk and Rose 2015). The scale h-coefficient shows the overall strength of association between all of the variables in that scale in representing a common trait.

Table 3 around here

The analysis showed the various indicators of political trust were mostly indicative of a common underlying trait of trust in a political institution (with one important exception considered below). The indicators are structured primarily by institution: in the language of MSA, an expression of trust in one institution to handle a particular policy area is indicative of the same underlying trait as an expression of trust in it to handle another policy area. The survey also uncovers evidence, however, that trust is strongly constrained by the perceived responsibilities and competencies of institutions. This observation leads us to ask the question: is trust a function 
of logics of appropriateness in relation to specific levels of institution? The affirmative answer to this question can be deduced from Table 2, which presented data relating to trust in institutions to handle specific policy areas and from Table 4, which presents the results of the logistic regression analysis. The data illustrates that French citizens are highly variable in terms of which institution they trust to handle their policy affairs, and that a substantial proportion have no faith in any institution to do so. Two broad logics account for the variable observed trust in institutions that we label as generic institutionalism and function-specific trust.

We label as generic institutionalism the phenomenon whereby one level of government is vested with a general purpose legitimacy, over and above instrumental considerations of policy specialisation. Thus framed, there are two ways of understanding generic institutionalism: proximity (closeness of the inhabitants of a territory) and policy pertinence (appropriate action of public authorities).

Proximity ('feeling close to') is the most visible manifestation of public authority: we label this dimension as proximity trust. In the case of proximity, the municipal government emerges as the reference point: proximity trust describes well the functioning of communes, as evidenced by the high rate of re-election of sitting mayors and the high levels of trust in localized institutions that are perceived as being close to local people. The principle of general purpose local authorities is part of the underlying fabric of the French model of territorial administration and explains why French local authorities are loosely bounded with overlapping responsibilities. The general competency clause (compétence générale d'administration) confers the power to develop 
policies on any matters in the general interest of the local authority, whether or not these competencies are formally recognised. Since the 2015 NOTRE law, only the communes are granted this right. The municipal government comes closest to achieving such a generic level of proximity trust, but is less and less central in terms of policy delivery. Communes have gradually lost competencies to 2000 or so inter-communal public corporations (EPCI) now covering virtually all of the country. There is a gap between micro -level trust and a lack of meso-level policy transparency, with the EPCI delivering urban public policy in the absence of direct democratic elections, a form of politics without policy at the local government level (Desage and Guéranger, 2016). Communes are trusted, but they represent more than ever a symbolic presence in France's countryside and small town landscape and are far less autonomous than even a decade ago. The new commune only marginally affects this conclusion (Pasquier, 2017).

As far as broad-based policy pertinence is concerned, trust is vested above all in the central government. In Table 2, the national government is perceived to be responsible, in some way, for virtually all of the policy items proposed. It benefits from a generic credibility that is not available to other, more task specific levels of government. Trusting the national government to best handle immigration, the national economy and the national territory, for example, are all expressions of an underlying generalized policy trust in the national government. Measures of trust in the national government are not strongly associated, however, with measures of trust in the other political institutions as well (as single-item survey questions would imply). 
Generic institutionalism contrasts with a form of 'function-specific institutional trust', in which faith in the capacity of institutions to address policy concerns is limited to the perceived functions of that institution. Function-specific institutional trust in the 96 departmental councils, for example, is expressed in the fields of transport, growth, immigration and the environment - a more limited range of policy areas that relate to the responsibilities and capacities of the departments. The departmental councils have evolved into agencies of the local welfare State, with minimal formal policy autonomy (though variable capacity, according to local configurations). In the case of the departments, losing the status as general purpose local authorities in the 2015 local government reform (known as the NOTRe law) was a bitter blow, far more so than for the regional councils, traditionally apt at framing their role in terms of strategic management and planning (Frinault, 2017). Likewise, the regions are trusted mainly in areas of their recognized competence, particularly that of economic development. The 2015 NOTRe law strengthened the regions in important respects (in their de facto role of coordination of territorial planning and economic development), though our survey above all demonstrated that the method retained for merging the 22 regions into 13 was widely contested by political elites and public opinion.

The paradox is evident between the crisis of state capacity in most of the policy fields mentioned above (abundantly commented in the academic literature), and the perception that the State retains the core distributive, redistributive and regulatory powers. These findings are illustrative of the continuing pertinence of the State in France and of national power as an overarching intellectual frame within which politics is debated (Cole, 2008). Of the other levels of government, the commune comes closest to achieving such a generic level of trust, which 
extends beyond narrowly defined competencies, and reflects the practice of the general administrative competency of French communes.

The analysis also reveals an exception. Scale one in Table 3 consisted of indicators of having no trust in any institution to handle the twelve policy areas, and the relationship between those indicators was stronger than for all the other scales identified. This shows that indications of no trust are themselves related in representing a common trait, specifically the tendency not to trust any political institution to achieve anything. Rather than representing a constrained generalized trust in a particular institution, this represents a generalized lack of trust in any political institution; essentially a form of political alienation in which respondents perceive that political institutions have neither the willingness nor capability to look after their interests (Dogan, 2005; Hardin, 2004; Southwell 2012; Fox 2015).

\section{Correlates of Function-Specific Institutional trust}

Having identified manifestations of function-specific trust, our next concern is with the relationship between individual characteristics typically associated with political trust in the literature - such as age, gender, education, socio-economic status or political ideology - and these expressions. The clusters of variables identified in the scales in Table 3 were merged into composite variables representing trust in the national government, the municipal authorities, regional authorities, the departments and the EU respectively. A variable was also created to represent institutional mistrust. This resulted in seven new variables measuring function-specific 
trust in each institution: trust in the national government and municipal authorities was measured on a scale from 0 (meaning no trust at all) to 12 (meaning considerable trust across all policy areas); trust in the departmental authorities was measured on a scale from 0 (no trust) to 6 (considerable trust); trust in the regional authorities was measured on a scale from 0 (no trust) to 10 (considerable trust), and trust in the EU was measured on a scale from 0 (no trust) to 7 (considerable trust). The differences in the scales reflect the differences in the range of policy areas related to function-specific trust in each institution; the national government scale is measured on a scale from 0 to 12 because trust was found to be represented by measures of all 12 policy areas in the survey; the departments, in contrast, are measured on a scale from 0 to 6 because trust was only represented by 6 of the policy areas covered by the survey. The differences in ranges is not indicative of differences in the maximum level of trust an individual can feel for a particular institution (in all cases, the maximum score means the highest level of trust); the only consequences is that the larger scales allow for more variation.

Regression analyses were used to identify the key predictors of function-specific trust in each institution. The predictors represented the influence of demography (age, gender, social class, education and having children), party, political ideology and locality. Table 4 presents the results of these analyses.

--- Table 4 around here --- 
The analyses reveal several important findings about the drivers of trust in government institutions. Existing accounts identify some relationship (albeit weak) between demographics and trust; for Rouban (2016), distrust is linked to the level of education, socioeconomic status, age, and political affiliation. The highly educated, the wealthy, the elderly, and supporters of moderate parties are more trusting than other groups, though "trust" in politics has been declining in all categories. Our survey also suggests that demography has a significant impact of some sort on trust in all of the institutions, but the nature of the effect varies. Older people trust departments and regional authorities more than those under 45, though age has no effect on trust in the national government or city/communal authorities. On the other hand, youth is associated with higher trust in the European Union, which corresponds to the established finding that young people are typically associated with lower levels of Euroscepticism (Hooghe and Marks 2005; Gabel 1998; Fox and Pearce 2017). Our main finding is that some characteristics are statistically significant predictors of trust in one institution, but not another. Women, for example, are typically less trusting of the national government and the EU than men once all of the other factors in the model have been controlled for. Gender has no effect, however, on trust in any of the other institutions. Education also has a modest impact; the one significant effect from education is that those with a degree are typically more trusting of the government. Social class, perhaps surprisingly, has no significant effect on function-specific institutional trust.

The key analytical point is that institutional logics matter more than demographics. This point is illustrated by comparing the r-squared statistics of the regression models. These figures show the proportion of variance in trust explained by the independent variables in the model. The most successful model is that for trust in the national government, which shows that demography, 
region and political ideology account for almost fifteen per cent of variance; these same traits explain less than three per cent of variance in trust in the departments, however, and less than two per cent in the municipal authorities. The characteristics that affect function-specific trust in institutions, therefore, vary substantially. Contrary to assumptions in much existing literature, it is not possible identify a particular social group as being more or less trusting than others in all governmental institutions. Instead, trust needs to be examined both within the context of a specific institution, and within the remit of the primary responsibilities of that institution.

Locality is also shown to be an influential trait, having a significant effect on political trust in the national government, regional authorities, and the departments. On average, people living in Paris are the most trusting of the national government, followed by those living in the South East, and then the North West ${ }^{2}$. Those living in the North East and South West are the least trusting. The relationship is almost reversed for regional authorities: those living in Paris and the South East are the least trusting. Those in the South West are rather more trusting, with no significant difference between them and people living in the North East or North West. Finally, those living in Paris stand out for being more trusting of central government and less trusting of the local and regional authorities. As central government itself is based in Paris, this likely makes Parisians more confident that the central government understands and reflects their concerns than those elsewhere. It may also explain their relative lack of trust in decentralised institutions, most

\footnotetext{
2 The analysis takes You Gov's proprietary panel - which divides France into Paris and its regions, the South-East, the South-West, the North East and the North West - as the basis for analyzing locality effects, though these labels do not refer to the actual names of the 13 French regions. The objective is to identify broad territoriality effects.
} 
of which are established to represent a particular local or regional interest in competition with Paris for resources (Prat, 2016). However, the effect of locality on political trust varies considerably by institution, and the influence of place-specific factors on political trust overall is limited.

The one set of characteristics that consistently prove to be very influential are those relating to political ideology and party identification, which suggests (perhaps unsurprisingly) that functionspecific institutional trust is more a function of political concerns than sociological characteristics. These are significantly related to trust in every institution examined, often with substantial effects. Typically, those who identify positively with political parties are more trusting than those who do not - with the exception of those who identify with the Front National and those with no party identification. The FN bases its support on hostility towards and criticism of the political elite that dominate most political institutions, and particularly cites failures in policy areas such as employment, immigration and European integration as evidence of the abandoning by the political elite of many French citizens (Crépon et. al., 2015). The logical corollary is that FN identifiers are likely to be among the least trusting of the willingness and capability of political institutions to address their concerns.

An interesting question is also raised by the fact that those with no party identification consistently have less trust in government, and are far more likely not to trust any institution than identifiers of any political party except for the Front National. While the causal relationship remains unclear (does not identifying with a party make someone less trusting, or are they less 
trusting because they do not identify with a political party?), this suggests that not identifying with a political party is indicative the political alienation mentioned above in France, reflecting the dissatisfaction of individuals with the political options available to them. The result of 2017 presidential election campaign (won by the centrist Macron who defeated the FN's Le Pen, with neither the Socialists nor the Republicans reaching the run-of) revealed the depth of anti-party sentiments in the French electorate, and may have been related to this finding, as people who had lost faith in the capacity of the mainstream parties (that typically control the political institutions studied in this survey) to address their concerns turned to the alternative presented by Macron.

Finally, political ideology also plays an important role in shaping political trust, independently of the effect of identifying with a particular party. The effect is variable across institutions, and does not suggest a consistent pattern in which right or left is associated with more or less trust in particular government bodies. Typically, those who are more right wing tend to be less trusting of central government than centrists or left wingers. One notable stand out group is those who identify themselves as 'very left wing'; this group is significantly less likely to trust any political institution than other left-wingers, and is particularly distrustful of regional authorities. Given that party affiliation has been controlled for when estimating this effect, this suggests that there is a distinct effect associated with being 'very left wing' independent of one’s support for or opposition to a particular political party that promotes a particularly distrustful view of France’s political institutions. In the context of France, this finding elucidates the success of the France 
Unbounded candidate Jean-Luc Melenchon in the 2017 French presidential election, surfing the wave of anti-partyism and on the theme of dégagisme ${ }^{3}$.

\section{Conclusion}

While many French citizens still trust their political institutions and government, French democracy is hardly a perfect example of a satisfied citizenry. Around four in every ten citizens do not feel that any of their governmental institutions can be trusted to best manage the policy issues that matter to them, with trust in the departments and the European Union particularly low. This was found to be barely influenced by place or demography, and more significantly affected by political ideology and identification, with supporters of the Front National or of no party at all the most sceptical and alienated.

Further research is undoubtedly required to explore the factors which drive political trust within different levels of governance. There appeared to be no clear structuring role for heavy sociodemographic variables. Variation occurred more at the level of particular institutions than according to social class, gender, age or place (though there were certainly some important effects). Rather more evidence was found to support the proposition that party and ideology perform an important filtering role. Parties matter; the evidence from this survey suggests that

\footnotetext{
${ }^{3}$ Melenchon polled almost 20\%. Literally, dégagisme signifies removing existing elites and banishing them forever.
} 
the weakening of party identification has negative spillover effects for trust in democracy as a whole.

In our survey, general levels of trust were highest in the national government and municipal authorities but notably lower for departments, regions and the EU. These mixed results suggest that the 'closeness' of government may play some role but its relationship to political trust may be modest or at best complex. Indeed, when individual policy areas are considered, the levels of government with relatively low levels of general political trust, notably the EU and the departments, receive greater levels of trust in those areas in which they have key responsibilities.

The most pertinent explanation would appear to be a revised institutional one: trust is accorded to those institutions able to embody a comprehensive institutional order. The use of Mokken Scale Analysis allowed us to demonstrate that the national government is the most generically trusted institution: it is perceived to be responsible, in some way, for virtually all of the policy items proposed, hence benefits from a generic trust that is not available to other, more task specific levels of government. In this adaptation of new institutionalist thinking, the type of institution matters and distinct logics of institutional orders matter (Powell, 2007). In the case of France, economic crisis, the distrust of politicians and a general misunderstanding of the past decade of territorial reforms have increased mistrust in all political institutions. Insofar as institutional trust is retained, however, a form of social protection and policy competency is accorded to the national government, comforted by the proximity provided by municipal administrations, leaving the intermediary authorities (the 13 regional and 96 departmental 
councils) as the depositories of thin, more specialized legitimacies - and the EU largely ignored. The French government can take some comfort from the fact that it is the main depository of the citizen's residual trust. It ought to be a source of key concern for the French political elite, however, that more than one in three of their citizens feel that public authorities cannot be trusted, at any level of government, to handle key policy areas relating to the economy and immigration.

The You Gov survey suggests several areas for future study. The regression analyses show that political trust is highly variable depending on the institutional context; the survey suggests that it is not sensible to talk of generalised political trust in all governmental institutions, but that trust has to be broken down and analysed on an institution by institution basis. Are these findings generalizable to other comparable democracies, in particular those responding to Hooghe and Marks' multi-level governance type 1? Does state type (federal, union, unitary) determine, or at least strongly influence underpinning logics of institutional trust? The line of enquiry is worthy of further research. In terms of methods, the survey is a blunt tool, though it has the advantage of allowing a representative sample of a whole population to be studied, in this case the French electorate, and for sub-groups within that population to be compared. The project on which this article is based also integrates a qualitative dimension in ongoing fieldwork, whereby the survey is complemented by experimental and ethnographical methods. The main contribution of this article is to add a territorial dimension to debates on trust and to address the deficiency in the 
literature, which is dominated by studies of national or supranational trust; further comparative analysis is proposed to validate fully the findings. ${ }^{4}$

\title{
TABLES
}

\section{LIST OF REFERENCES}

\author{
ANES \\ Balme R., Marie J.-L. \& Rosenberg O (2003) 'Les motifs de la confiance (et de la défiance : \\ Intérêt, connaissance et conviction dans les formes du raisonnement politique' Revue \\ internationale de politique comparée 10 (3): 433-461. \\ Boy, D. et Chiche, J. (2010), 'Confiances’, in Boy, D., Cautres, B. \& Sauger, N. (2010), \\ Français des européens comme les autres, Paris : Presses de Sciences Po, pp. 45-71. \\ Braithwaite, V. \& Levi, M. (eds.) (1998) Trust and Governance New York: Russell Sage \\ Foundation.
}

\footnotetext{
${ }^{4}$ Note detailing the future comparative analysis to be undertaken.
} 
Brookover, W.B. \& Thomas, S. (1964) 'Self-Concept of Ability and School Achievement', Sociology of Education, 37 (3): 271 - 278.

Butler, D., Stokes, D. (1969) Political Change in Britain: Forces Shaping Electoral Choice, New York: St Martin's Press

Campbell, D.E. 2009 ‘Civic Engagement and Education: An Empirical Test of the Sorting Model’, American Journal of Political Science 53 (4): 771-86.

Carter, C. \& Pasquier, R. (2010) 'The Europeanization of regions as “spaces for politics”: a research agenda’ Regional and Federal Studies 20 (3): 295-314.

Cautrès B. (2017) 'Jusqu'ici tout va bien ? La démocratie de la défiance en année électorale’, Baromètre de la confiance politique 8, Paris : CEVIPOF.

CEVIPOF (2011) ‘La confiance dans tous ses états’. Les cahiers du Cevipof, 54, Paris : CEVIPOF. CEVIPOF (2014) 'Le baromètre de la confiance politique 5'. Consulted at : http://www.cevipof.com/fr/le-barometre-de-la-confiance-politique-du-cevipof/resultats-1/vague5/ (Date accessed: 24 July 2017)

CEVIPOF (2015), Le baromètre de la confiance politique 6. Consulted at: http://www.cevipof.com/fr/le-barometre-de-la-confiance-politique-du-cevipof/resultats1/vague5/ (Date accessed 24 July 2017)

Cheurfa, M. (2017), 'Les exceptions à la confiance politique’, Baromètre de la confiance politique 8, Paris : CEVIPOF. Consulted at : $\underline{\text { http://www.cevipof.com/fr/le-barometre-de-la-confiance- }}$ politique-du-cevipof/resultats-1/vague8/ (Date accessed: 24 July 2017) 
Chiche, J. \& Chanvril, F. (2014), Confiance en politique ; méthode et analyse, 8e colloque francophone sur les sondages, Dijon. Consulted at:

http://paperssondages14.sfds.asso.fr/submission_58.pdf (Date accessed 29 July, 2017)

Citrin, J. and Muste, C. (1999) ‘Trust in government’ In Robinson, J., P. Shaver and L.

Wrightsman (eds.) Measures of political attitudes, London: Academic Press, pp. 465-532.

Clarke, H.D., Sanders, D., Stewart, M.C., Whiteley, P. (2004) Political Choice in Britain, Oxford: Oxford University Press

Cole, A. \& John, P. (2001) Local Governance in England and France London: Routledge.

Cole, A. (2008) Governing and Governance in France Cambridge: Cambridge University Press

Cole, A., Harguindéguy, J.-B. Pasquier, R., Stafford I. \& de Visscher C. (2015) 'The States of Convergence of Territorial Governance’ Publius: the Journal of Federalism 45:2, 297-321.

Crépon, S., Dézé, A. \& Mayer N. (2015) (eds.), Les faux semblants du Front national. Sociologie d’un parti politique, Paris : Presses de Sciences Po.

Dalton, R.J. (2013) The Apartisan American, Thousand Oaks: CQ Press

Desage, F. and Guéranger, D. (2016) La Politique confisquée: sociologie des reformes et des institutions intercommunales, Bellecombe-en-Bauges: Editions du Croquant.

Dogan M. (1999) “Déficit de confiance dans les démocraties avancées - une analyse comparative”, VIème congrès de l’A.F.S.P. » Aix-en-Provence, 20 pp.

Dogan, M. (2005) (ed.) Political Mistrust and the Discrediting of Politicians, Boston : Brill. Entwistle, T.W. Downe, J. Guarneros-Meza V. \& S. Martin (2014) 'The multi-level governance of Wales: layer cake or marble cake?' The British Journal of Politics and International Relations, 16, 2, 310-325. 
European Social Survey Source Questionnaire Round 8 2016/17

Fisher, J., van Heerde, J. and Tucker, A. (2010) 'Does on trust judgement fit? Linking theory and empirics’ British Journal of Politics and International Relations, 12(2): 161- 88.

Fox, S. (2015) Apathy, Alienation and Young People: The Political Engagement of British Millennial, PhD Thesis: University of Nottingham

Fox, S., Pearce, S. (2017) 'The generational decay of Euroscepticism in the UK and the EU Referendum', Journal of Elections, Public Opinion and Parties, 28(1): 19-37

Frinault, T. (2017) De la décentralisation à la réforme territoriale. Invariances et mutations des institutions locales françaises Grenoble : unpublished HDR thesis.

Fukuyama, F. (1995) Trust: Social Virtues and the Creation of Prosperity New York: Free Press

Gabel, M. (1998) ‘Public Support for European Integration: An Empirical Test of Five Theories’, The Journal of Politics 60 (2): 333-54.

Grimmelikhuijsen, S.G. (2012) 'Linking transparency, knowledge and citizen trust in government: an experiment’ International Review of Administrative Sciences 78(1), 50-73.

Grimmelikhuijsen, S., Porumbescu, G., Hong, B. and Im, T. (2013) 'The Effect of Transparency on Trust in Government: A Cross-National Comparative Experiment' Public Administration Review 73 (4), 575-586.

Grossman, E. \& Sauger N. (2017), Pourquoi détestons-nous autant nos politiques ? Paris: Presses de Sciences-Po.

Hardin, R. (2002) Trust and Trustworthiness New York: Russell Sage Foundation.

Hardin, R. (2004) (ed.) Distrust New York: Russell Foundation. 
Hardin, R. (2006) Trust Cambridge: Polity Press.

Hetherington, M. J. (2005) Why Trust Matters: Declining Political Trust and the Demise of American Liberalism. Princeton: Princeton University Press.

Hetherington M. J. \& Husser J. A. (2012) ‘How Trust Matters: The Changing Political Relevance of Political Trust’ American Journal of Political Science 56 (2), 312-32.

Hibbing, J. R. \& Theisse-Morse, E. (2001) 'Process Preferences and American Politics: What the People want the Government to Be', American Political Science Review, 95 (1): 145-153.

Hooghe, L. \& Marks, G. 2005. “Calculation, Community and Cues: Public Opinion on European Integration” European Union Politics 6 (4): 419-443.

Hooghe, L., \& Marks. G. (2001) ‘Types of Multi-Level Governance’ European Integration online Papers 5 (11): 1-31. Consulted on July 28 ${ }^{\text {th }}$, 2017, at: http://eiop.or.at/eiop/texte/2001$\underline{011 a . h t m}$

Kaase M. and Newton K. (1995) Beliefs in Government Oxford: Oxford University Press. Kaase, M. (1999) 'Interpersonal trust, political trust and non-institutionalised political participation in Western Europe’, West European Politics 22 (3), 1-21.

Keele, L. (2007); 'Social Capital and the Dynamics of Trust in Government' American Journal of Political Science, 51 (2), pp. 241-254

Koppenjan, J. and Klijn, E.H. (2004) Managing Uncertainties in Networks: A Network Approach to Problem Solving and Decision Making, London: Routledge.

Meijer, E.,'t Hart, P. and Worthy, B. (2015) 'Assessing Government Transparency: An Interpretive Framework’ Administration \& Society, p.0095399715598341. 
Muñoz, J., Torcal, M. and Bonet, E. (2011) 'Institutional trust and multilevel government in the European Union: Congruence or compensation?’ European Union Politics 12 (4), 551-574.

Newton, K. (2007) 'Social and Political Trust’ in Dalton, R.J. and Klingemann, H. (eds.) The Oxford Handbook of Political Behaviour, Oxford: OUP, 342-361.

Newton, K. and Zmerli, S. (2011) ‘Three forms of trust and their association’ European

Political Science Review 3 (2), 169-200.

Nooteboom, B. (2002) Trust: Forms, Foundations, Functions, Failures and Figures Cheltenham: Edward Elgar.

Norris P. (1998), Critical Citizens. Global Support for Democratic Government, Oxford: Oxford University Press.

O’Neill, O. (2002) A Question of Trust Cambridge: Cambridge University Press.

Parker, G., Parker, R. and Towner, T.L. (2014) 'Rethinking the Meaning and Measurement of Political Trust' in Eder, C., Mochmann, I.C. and Quandt, M. (eds.) Political Trust and Disenchantment with Politics: International Perspectives, Leiden: Brill.

Pew Research (2017) 'Public Trust in Government Remains Near Historic Lows as Partisan Attitudes Shift' Pew Research Website (http://www.peoplepress.org/2017/05/03/public-trust-in-government-remains-near-historic-lows-as- partisanattitudes-shift/, accessed 28/05/2017)

Parrado, S., Van Ryzin, G. G., Bovaird, T., \& Löffler, E. (2013). Correlates of co-production: Evidence from a Five-Nation Survey of Citizens. International Public Management Journal, 16 (1), 85-112. 
Parry, G., Moyser, G., Day, N. (1992) Political participation and democracy in Britain, Cambridge: Cambridge University Press.

Pasquier, R. (2017) ‘Une révolution territoriale silencieuse ? Les communes nouvelles entre européanisation et gouvernance territoriale', Revue française d'administration publique 2 :162, 239-252.

Pattie, C., Seyd, P., Whiteley, P. (2004) Citizenship in Britain: Values, Participation and Democracy, Cambridge: Cambridge University Press.

Piatonni, S. (2010) The Theory of Multi-Level Governance, Oxford: Oxford University Press

Powell, W.W. (2007) ‘The New Institutionalism'. In The International Encyclopedia of Organization Studies Thousand Oaks, California: Sage, pp. 956-8.

Prat, P. (2016) ‘The Greater Paris debate. The French State and its capital region’, in Cole, A., \& Payre, R. (eds.), Cities as Political Objects Cheltenham: Edward Elgar, pp. 56-78.

Putnam, R.D. (1993) Making Democracy Work: Civic Traditions in Modern Italy, Princeton: Princeton University Press.

Putnam, R.D. (2000) Bowling Alone: The Collapse and Revival of American Community New York: Simon \& Schuster.

Rouban L. (2016), 'Les seniors au centre de l'élection présidentielle 2017’, Etude n 1, L'enquête électoral française: comprendre 2017, Paris: CEVIPOF, pp 1-8. Consulted at: http://www.youscribe.com/catalogue/documents/actualite-et-debat-de-societe/politique/les$\underline{\text { seniors-au-centre-de-l-election-presidentielle-de-2017-etude-n-1-2726036 }}$ (Date accessed: $29^{\text {th }}$ July 2017). 
Schmidt, V. (2006) Democracy in Europe Oxford: Oxford University Press.

Seligman, A.B. (1997) The Problem of Trust Princeton: Princeton University Press.

Seyd, B. (2016) ‘How should we measure political trust?’ Paper for PSA Annual Conference, Brighton, 21-23.

Single, E., Kandel, D. \& Faust, R. (1974) 'Patterns of Multiple Drug Use in High School', Journal of Health and Social Behaviour, 15 (4), 344 - 357.

Sintomer, Y., \& De Maillard, J. (2007). The limits to local participation and deliberation in the French 'politique de la ville’. European Journal of Political Research, 46 (4), 503-529.

Stimson J. (2004) Tides of Consent: How Public Opinion Shapes American Politics New York, Cambridge University Press.

Stimson J., Tiberj V. \& Thiébaut C. (2010) 'Le mood, un nouvel instrument au service de l'analyse dynamique des opinions : application aux évolutions de la xénophobie en France (19992009)' Revue française de science politique 60 (5), 901-926.

Stone C. (1989) Regime Politics: Governing Atlanta Lawrence: University Press of Kansas.

Southwell, P. (2012) 'Political Alienation: Behavioural Implications of Efficacy and Trust in the 2008 US Presidential Election', Review of European Studies, 4 (2), 71-77.

Taber, C. S. \& and Lodge M. (2006) 'Motivated Skepticism in the Evaluation of Political Beliefs' American Journal of Political Science, 50 (3), pp. 755-769.

Tilly, C. (2005) Trust and Rule Cambridge: Cambridge University Press.

Uslaner, E.M. (2002) The Moral Foundations of Trust, Cambridge: Cambridge University Press. 
Van Assche, D. \& Dierickx, G. (2007) 'The decentralisation of city government and the restoration of political trust', Local Government Studies, 33 (1), 25-47.

Van de Walle, S., van Roosbroek, S. and Bouckaert, G. (2008) 'Trust in the public sector: is there any evidence for a long-term decline? International Review of Administrative Sciences 74(1), 47-64.

Van der Eijk, C. Rose, J. (2015) 'Risky Business: Factor Analysis of Survey Data - Assessing the Probability of Incorrect Dimensionalisation', available at http://journals.plos.org/plosone/article?id=10.1371/journal.pone.0118900 [Accessed 24th May 2015]

Van der Eijk, C., Franklin, M.N. 2009. Elections and Voters Basingstoke: Palgrave Macmillan. Van der Meer, T. \& Hakhverdian, A. (2017) 'Political Trust as the Evaluation of Process and Performance: A Cross-National Study of 42 European Countries’ Political Studies 65 (1), 81102.

Van Schuur, W.H. (2003) 'Mokken Scale Analysis: Between the Guttman Scale and Parametric Item Response Theory’, Political Analysis, 11 (1), 139-163.

Van Schuur, W.H. (2011) Ordinal Item Response Theory: Mokken Scale Analysis London: Sage Publications.

Warren, M.E. (ed.) (1999) Democracy and Trust Cambridge: Cambridge University Press. 
Whiteley, R., Clarke, H.D., Sanders, D. \& Stewart, M.C. (2013), Affluence, Austerity and Electoral Change in Britain Cambridge: Cambridge University Press.

WVS Wave 6 (2010-2014)

Yamaguchi, K. \& Kandel, D.B. (1984) 'Patterns of Drug Use from Adolescence to Young

Adulthood: II. Sequences of Progression', American Journal of Public Health, 74 (7) 668 - 672.

Zmerli, S. and Hooghe, M. (2011) 'Introduction: The Context of Political Trust' in Zmerli, S. and Hooghe, M. (eds.) (2011) Political Trust: Why Context Matters (Colchester: ECPR), pp.112. 